\title{
An Ocean of Discovery: Biodiversity Beyond the Census of Marine Life
}

Author

Affiliation
Paul V. R. Snelgrove

Department of Ocean Sciences and Biology Department, Memorial University of Newfoundland, St. John's NL, Canada

\author{
Key words \\ - biodiversity \\ - taxonomy \\ - invertebrates \\ - Census of Marine Life \\ - marine bioprospecting \\ - biogeography
}

\section{Abstract \\ $\nabla$ \\ The 70\% of Earth's surface covered by oceans sup- ports significant biological diversity and immense untapped potential for marine bioproducts. The recently completed international Census of Ma- rine Life (2000-2010) invested heavily in evaluat- ing the diversity, abundance, and distribution of life in the ocean but concluded that at least $50 \%$ and potentially $>90 \%$ of marine species remain undescribed by science. Despite this potential, and numerous successes spanning pharmaceuti- cals, nutraceuticals, anti-foulants and adhesives, biofuels, biocatalysts (enzymes), and cosmetics, \\ Introduction - An Ocean of Discovery $\nabla$}

Bioprospectors have long recognized the opportunity for discovery from ocean environments, despite a slow start to marine bioproduct development [1]. The immense size and range of life in the oceans point to great potential for discovery that surpasses all other environments on Earth. Globally, oceans cover 70\% of the Earth's surface, encompassing $>90 \%$ of the known biosphere volume [2]. This recognition stems, in part, from the large pool of potential "raw material" for marine bioproducts, namely the wide diversity of ocean life. The international Census of Marine Life (CoML) that ended in 2010 created a whole new level of interest and recognition of marine biodiversity for a wide range of ocean stakeholders. This 10-year program united some 2700 researchers from over 80 countries around the world to catalyze discoveries on the diversity, distribution, and abundance of life in the ocean [2]. The program included 17 projects that spanned from microbes to marine mammals and from the intertidal zone to the deep plains [3]. When the program officially ended in 2010, participants estimated that they had found some 5000 new spe- several impediments have slowed marine bioproduct development. First, the sheer size of the ocean constrains comprehensive exploration. Second, marine taxonomists and ecologists generally do not focus on the most promising groups for bioproduct development. Third, the geographic mismatch between (often remote) biodiversity hotspots and science capacity limit discovery. Despite these challenges, new ocean sampling tools (digital imaging, remote vehicles, genetic approaches, in situ samplers), many developed or improved during the Census of Marine Life, should enhance future marine biodiversity and thus marine bioproduct discovery.

cies [2]. Noting typical lag times between the collection of new species and their formal description in the scientific literature of seven years and that some novel species may sit in specimen jars unrecognized for a century or more [4], the full range of CoML species discovery may not be fully known for another decade or more. Although none of the CoML projects considered bioactive compounds and the scientific description of those estimated new species will probably take decades to complete, the technologies and new information on biodiversity that continue to emerge from that program and related research illustrate the potential for discovery of new environments, new species, and new processes. These findings also point to great potential for marine natural product discovery that could surpass all other environments on Earth.

Despite greater numbers of documented species [5] and established bioactive compounds for land biota compared with ocean biota [6], the oceans nonetheless support substantially higher diversity at a higher taxonomic level (i.e., taxonomic distinctness), and thus may well eventually yield more species and a greater pool of bioactive compounds than all other environments combined 
[7]. For example, the oceans house 34 of 36 known animal phyla in contrast to the 17 found on land; 15 phyla occur exclusively in the oceans. From metabolically active microbes deep in the ocean seafloor crust [8] to seabirds that soar hundreds of meters above the ocean [9] to the fishes and invertebrates that migrate thousands of meters through the deep ocean on a daily basis [10], our recognition of the diversity of life and range of specialized habitats in the oceans continues to expand every year. New technologies for observing, sampling, and recognizing ocean life $[2$, 11], many developed or enhanced during the CoML, all point towards an ocean of discovery. For example, the development of new genetic tools offers a workaround to the problem that scientists can cultivate fewer than $1 \%$ of marine microbes; these tools suggest immense microbial diversity that could reach a billion different types [12]. The diverse adaptations of marine organisms to high pressure, high and low temperatures, salt, and tolerance to environments with elevated hydrogen sulphide, methane efflux, and low oxygen all point to an immense opportunity for bioprospecting. Importantly, opportunities could emerge that utilize genetic as well as species diversity to address a wide range of societal needs.

\section{An Ocean of Opportunity - Marine Bioprospecting to Date \\ $\nabla$}

Pharmaceuticals, nutraceuticals, anti-foulants and adhesives, biofuels, biocatalysts (enzymes), and cosmetics all utilize products from marine organisms. Of these categories, medically approved pharmaceuticals represent the least productive line of marine bioprospecting to date, with the first drug approved for sale in 2004 - a chronic pain product produced from a marine snail neurotoxin. Nucleosides identified from marine sponges had attracted great promise as far back as the 1950s and inspired synthetic U.S. Food and Drug Administration (FDA) approved pharmaceuticals such as cytarabine decades ago [13], but the low success rate in the direct production of marine pharmaceuticals that followed has been particularly discouraging. Drug approval typically requires an 8- to 15-year period from discovery to market, with an estimated typical development price tag of US\$900 million and hundreds of thousands of failures for every successful commercial product [14]. Although the FDA has approved only seven drugs derived from marine organisms [15], the success rate relative to the 28000 registered marine products compares favorably with terrestrial products. Furthermore, numerous other products currently in clinical trial in tandem with the potential application of marine natural products for inhibiting pain [1], different hallmarks of cancer [16], asthma [17], and herpes simplex treatment [18] points to major research potential and interest.

In contrast, marine organisms have already yielded a wide range of nutraceuticals beneficial to human health [19], with significant growth in the European and Asian nutraceutical industries totalling US $\$ 1.5$ billion in 2009 and expected growth to US $\$ 180$ billion by 2017 [19]. These products span from vitamins and minerals and food supplements, such as highly popular fish omega-3 oils, to compounds with cancer prevention, anti-inflammatory, antioxidant, and antimicrobial activities [20] to restorative cosmetics, the latter often derived from marine algae. Cosmetics include materials developed for application to human bodies for cleansing, protection, or altering appearance without affecting body structure or function [21]. Potential cosmetics from marine organisms span from sunscreen compounds derived from algal symbionts in invertebrates [22] and aquatic vertebrates [23] to marine algal-derived anti-photoaging agents and skin whiteners in Asia [24]. A wide range of marine algal products has also been developed to treat multiple skin conditions [24].

On the one hand, the banning of many biocidal compounds from marine applications in tandem with a need to combat fouling organisms has catalyzed successful efforts to develop naturally derived antifoulants [25], including many from marine algae. On the other hand, the bio-adhesives industry capitalizes on marine organisms such as barnacles and mussels that produce strong natural glues that adhere under water. The capacity of sea stars to quickly attach and detach from hard surfaces points to intriguing possibilities for temporary adhesives [26].

Food and energy production from marine organisms also shows great promise. The utility of transgenic technology to enhance aquaculture has been recognized for decades; for example, the transfer of antifreeze proteins from cod to salmon can extend aquaculture production geographically and seasonally [27] and improve growth rates. Indeed, Atlantic salmon recently became the first FDA approved genetically modified animal. Marine algae, and diatoms specifically, show great potential for biofuel production, noting the capacity of some species to produce oils and carbohydrates from photosynthesis that may yield different biofuels [28]. Bioluminescence proteins extracted from marine organisms have also been widely used in the biotechnology industry and in research [29]. Enzymes produced by specialized marine organisms spanning from microbes to algae to animals remain stable under specific environmental conditions (high pressure, extreme hot or cold temperatures, high salt, and hydrogen sulphide and methane rich as well as oxygen poor water) and can act on proteins, lipids, carbohydrates, and other compounds. The utility of these compounds remains largely unknown, with most of the current focus on inventory [30].

\section{An Ocean of Opportunity - Biodiversity Technologies $\nabla$}

Technologies developed over the last decade have rapidly advanced science capacity for new species discovery, and include tools that expedite the discovery of new habitats, others that facilitate specimen collection, and others that expedite or clarify taxonomic descriptions. Some of these capacities were developed or extended within the CoML, whereas other techniques emerged in parallel.

Dramatic improvements in acoustic tools, such as multibeam acoustics and associated analytical software capabilities that use sound waves to map seabed, greatly enhance the capacity for habitat discovery [31]. The huge areas of ocean habitat on Earth limit the proportion of well-quantified habitats to date, however, seabed mapping has matured in its capacity to differentiate broadly different habitat types and produce highly detailed physical maps [31]. Habitat offers the best predictor of species distributions $[32,33]$ and thus the likelihood of identifying promising locations for species discovery. Ironically, coastal depths can be especially challenging to map from surface ships because vessels required for multibeam equipment cannot efficiently navigate the shallowest waters without significant risk. Although opticalbased remote sensing methods such as LIDAR (Light Detection and Ranging) can image wide swaths of shallow seabeds under clear waters [34], water actually attenuates light quickly, typically $100 \mathrm{~s}$ of $\mathrm{m}$ or less. This opacity limits optical mapping tools, including SCUBA, to a small percent of ocean depths. Noting the 
ephemeral, highly patchy, and discrete nature of some marine habitats such as cold seeps and hydrothermal vents $[35,36]$, the expansion of exploration of ocean biota from ship-based sampling to submersibles [37] and, more recently, remotely operated vehicles (ROVs) and autonomous underwater vehicles (AUVs) [11] greatly increases the potential for habitat discovery, particularly in light of major advances in digital imaging and analysis. Submersibles and ROVs also provide excellent platforms for specimen collection when equipped to collect delicate biota from highly specialized locations, as illustrated by the initial collections of novel chemosymbionts from hydrothermal vents [38]. Nonetheless, only nine nations currently operate deep diving submersibles [39] and the various nets, grabs, and bottles used for the last century continue to dominate the tools used in the collection of marine specimens, including new species [2].

New technologies enable habitat discovery through means other than habitat surveys. New and improved environmental sensors that measure a wide range of chemical constituents, including hydrogen sulphide, oxygen, temperature, methane, $\mathrm{pH}$, salinity, and other variables [40], can help in discovering unique or specialized environments. Improved stability of such sensors, combined with ever-increasing miniaturization, enable the use on sampling platforms such as ocean gliders [41] and ARGO floats [42] that drift across large swaths of ocean collecting data, AUVs [43], and underwater cabled observatories [44]. Collectively, these tools provide opportunities to identify novel environments to catalyze new discovery.

\section{The Taxonomic Impediment to Species Discovery} $\nabla$

As time-consuming and expensive as the collection of specimens can be, the process of documenting biodiversity itself requires complex taxonomic scrutiny, and even then taxonomic confusion may arise from morphologically similar species [45], misspellings, and misidentification. The World Register of Marine Species (WoRMS), a partner of the CoML program, is cataloging all valid scientific names for marine species, with the current count at just under 230000 of the $\sim 245000$ known species [46]; this same project documented 56 different taxonomic names for a single species, illustrating the confusion arising from taxonomic errors. Fortunately, new technologies developed by the genetics revolution already minimize ambiguities and accelerate species discovery rates. Genetic barcoding, which first referred to animal identification using the mitochondrial cytochrome c oxidase I (COI) gene [47], has expanded to utilize other genetic identifiers [48, 49], and now provides unambiguous species identification spanning from microbes to whales. Species identification using genetic barcoding requires comparison of genetic material from specimens to library sequences of similar genetic material. Therefore, the current lack of a complete library of known and unknown marine species constrains genetic taxonomy and will continue to do so until every species has been barcoded, a very long-term prospect given the many unknown species and current rates of species discovery (see below). Moreover, barcoding may produce errors just as serious as those that have plagued morphological taxonomy, and points to the need for collaborative approaches between researchers using genetic and morphological-based taxonomy. Nonetheless, barcoding provides an unambiguous tool for differentiating among specimens within the library, and the convergence of barcoding with morphological taxonomy offers huge potential in cataloging ocean life.
High-throughput mass sequencing encompasses several different genetic approaches, including environmental DNA sampling that can be likened to "biota in a blender"; in essence, analysis of gene sequences within a sample of water, sediment, or even biota within organisms, produces estimates of the numbers of species or operational taxonomic units (microbiologists in particular use OTU to refer to genetically distinct life forms that may or may not conform to different species definitions). Mass sequencing can therefore identify the number of different life forms in a sample, even those forms undescribed taxonomically. Indeed, concerns about the rapid loss of coral reef diversity prompted CoML scientists to propose the mass sequencing of reef biota, even if simply to produce a list of genetic identifiers of unknown species [50]. At least the level of biodiversity loss might be quantifiable even in poorly known areas. Genetic techniques also allow for the identification of specific gene expressions, such as toxic strains of dinoflagellates. Indeed, the Environmental Sample Processor was developed to collect in situ samples and test for the presence of a particular gene in microbial samples or in larval invertebrates [51]. When deployed on ocean observatories that relay data to shore [44], this strategy could provide real-time information on the presence and activity of species of interest.

For some of these new technologies, the application for bioprospecting may not be immediately obvious. Certainly any technologies that facilitate specimen collection can expedite the discovery of new bioproducts, and mass-sequencing tools can help to identify biodiversity hotspots that could be targeted for exploration. Similarly, improved sensors and platforms offer the promise of the discovery of new environments or at least new habitat locations with potentially novel species, such as the first discovery of hydrothermal vents in the Southern Ocean recently [52].

\section{Novel Environments}

$\nabla$

The propagation of technologies that enable new habitat discovery offers a two-pronged benefit for marine bioprospecting. New habitats often support novel species and thus bioproduct potential, but perhaps more importantly, by human standards, the extremes of temperature, chemistry, and pressure that characterize many of these newly discovered environments require specialized biota with specific enzymes and physiological adaptations. The examples below illustrate new environments, most discovered in the last few decades. Not surprisingly, most novel habitat discoveries occur in deep and remote waters [11]. In some of these environments, such as hydrothermal vents, new species discoveries show no sign of slowing down [4], even though the first reports of unique hydrothermal vent fauna appeared almost 40 years ago [38].

Ice biota offers a shallow-water example of novel habitats highlighted by the CoML. Scientists first reported cold and ice-adapted organisms and ice enzymes long ago [53], and transgenic technology has already improved aquaculture growth rates of cold water fishes [54], however, knowledge of entire ice-associated communities that span from microbes to fishes and marine mammals only recently came into sharp focus $[55,56]$. From a bioprospecting perspective, the low diversity of ice biota offers modest promise for new bioproducts with only a few species per major taxonomic group [53], but the extreme conditions in which these species live (temperatures $<-10^{\circ} \mathrm{C}$ and salinities $>100 \mathrm{ppt}$ ) suggest potentially unusual physiological adaptations. Polar environments more generally support organisms capable 
of anabolic and catabolic processes at cold temperatures that could offer significant potential for new habitat discovery, particularly given the large areas of undersampled Arctic and Antarctic environments such as those under multiyear ice $[53,57]$ or remote deep fjords.

Deep-water coral patches were first reported in the 1800s [58], but first recognized as distinct habitats in the early 20th century [59]. Habitat models now predict likely locations for corals on seamounts [60] and are based on environmental characteristics $[33,61]$. We now know that deep-water corals [62] and sponges provide a distinct habitat for a variety of invertebrates and microbes, and bioprospecting has already begun to target sponge microbes [63] and a wide range of natural products from corals in general [6].

The discovery of hydrothermal vents in 1978 changed our view of life on Earth and illustrated the potential for the discovery of fundamentally different ecosystems, in this case an ecosystem fueled not by sunlight but by chemicals such as hydrogen sulphide and methane emitted from superheated seawater within the seafloor [38]. The capacity of some vent organisms to tolerate normally toxic hydrogen sulphide, with little to no oxygen, and seawater heated well above ambient levels [64] forced the rewriting of textbooks describing metabolic pathways, enzyme characteristics, adaptation, and even basic ecology. The complex biogeography of hydothermal vents [65] and high levels of endemism and taxonomic distinctness [66] add to the expectation of discovery. Research cruises in recent years have discovered new vent habitats in the Southern [52], Indian [67], and Arctic [68] Oceans, with expectations of more vent habitats to come [36].

The discovery of seeps and their chemosynthetic communities [69] some 30 years ago was thought to represent a habitat extension of hydrothermal vents, but we now recognize seeps, which may include methane, natural gas, or hydrocarbon emissions, as quite distinct habitats with little species overlap with vents [66] and high rates of endemism [70]. Although we know that seeps, and the mud volcanoes that characterize some seep environments, occur widely in all oceans [71], new discoveries continue, such as the first report of an Antarctic seep just a decade ago [72]. Oxygen minimum zones and anoxic basins exclude many or most life forms, respectively $[73,74]$, but the taxa that can tolerate such conditions necessarily display specialized adaptations and physiologies to cope with low oxygen. Anoxic basins, such as those at 3200-3600 $\mathrm{m}$ in the deep Mediterranean, exclude most life forms other than specialized bacteria and Archaea [74]. But DNA evidence points to the presence of living Protista [75]; metabolically active species from the animal phylum Loricifera with specialized organelles and symbionts were recently reported from the anoxic L'Atalante Basin [76].

The last decade also saw recognition of the "deep biosphere", where "deep" refers to depths of more than $1000 \mathrm{~m}$ below seafloor sediments deep in the Earth's crust in an environment thought devoid of life until just two decades ago [8]. The presence of metabolically active microbes in these environments points to capacities to utilize extremely limited resources and/or a greater prevalence of symbioses than previously recognized [11].

These findings suggest that our current expectations of adaptations and life forms underestimate the novelty of nature and physiology, and the associated potential for discovery of fundamentally novel bioproducts and processes in the global oceans. But new species discovery hardly requires new environments, noting that even well-studied ocean regions such as the Gulf of Maine continue to yield new species [77]. In addition to discrete, hard-to-locate habitats such as those described above, the sheer volume of the ocean and the massive volume of biological habitats it encompasses point to a discouragingly large potential for species discovery. Indeed, science has sampled only a few percent of the global oceans $[4,78]$ and although specific habitats such as coral reefs have yielded the most natural products to date, the reality is that the $95 \%$ of the global biosphere encompassed by the oceans offers great potential for species and habitat discovery.

\section{Who - Known and Unknown Diversity \\ $\nabla$}

So where does this plethora of new tools leave us in terms of completely documenting ocean diversity? The short answer is that we probably have a very long way to go. Despite the investment of many millions of U.S. dollars in the CoML, many unknowns remain and the program illustrated the unknown as effectively as the newly known for species discovery. Marine scientists currently describe about 1650 new species per year [79], but available taxonomists primarily constrain that number [80] more than the availability of novel species. The technologies described above can facilitate, but not overcome, this "taxonomic impediment" [81]. Even marine experts cannot agree on the correct order of magnitude of unknown species, with total species projections beyond 10 million [7,82] to as little as 300000 [83], with median total marine species projections of 1 million [5] to 2 million [84]. Importantly, these estimates do not include microbes, whose diversity could number over a billion [12]. A simple calculation based on a prediction of 2 million species and a stable annual description rate of 1650 new species per year suggests that we might expect to finish inventorying marine animals in about 1000 years. This gap is particularly interesting in light of the rapid increase in microbial patents in recent years, catalyzed by the genetics revolution [85]. Although a complete marine species inventory looks highly unlikely in any of our lifetimes, or perhaps even those of our great, great, great grandchildren, we have sufficient knowledge to ask where new discoveries are most likely and which groups of organisms are poorly versus well described. Although our knowledge of marine biodiversity decreases with the size of organisms, new species include some large-sized taxa such as the 3-kg lobster discovered off the coast of Africa [86]. Even widespread species can elude scientists, such as Prochlorococcus, first reported in 1988 [87] and now recognized as the most abundant photosynthetic organism on Earth.

The rates of new species description vary hugely among animal phyla, with a strong bias towards crustaceans, molluscs, and fishes [79]. Not surprisingly, projections of unknowns based on surveys of taxonomic experts for different major taxa [5] do not map well onto taxonomic effort in that fishes are relatively well known $(<20 \%$ unknown), whereas the least known major taxa include nematodes ( $>81 \%$ unknown), flatworms ( $>67 \%$ unknown), sponges (>67\% unknown), and molluscs (>64\% unknown) [5]. Several taxonomic orders of crustaceans also have projected unknowns that exceed $60 \%$. This bias reflects several factors [79], including the number of practicing taxonomists working on a given group, the contributions of amateur taxonomists (significant for molluscs and crustaceans), and the challenge in collecting and analyzing some of the smaller groups, noting the inverse relationship between size and taxonomic completion [88]. Intriguingly, the excellent mollusc taxonomist Philippe Bouchet commented that "the taxa for which [taxonomic extrapolations] are fairly accurate (fishes, echinoderms, decapods) con- 
tribute little to the global numbers, whereas for the taxa contributing much (parasites, nematodes) the estimates are vague" [79].

\section{Whence - The Geography of Species Discovery $\nabla$}

The geography of discovery reflects a combination of patterns of total biodiversity based on current knowledge (i.e., the available species pool) and the degree to which different habitats have been sampled (i.e., the total area of that habitat and proportion of those habitats sampled). The seafloor generally supports a far greater diversity of animals than the water column above it, noting that zooplankton account for only an estimated 7000 species [89] of the $\sim 245000$ described marine species [46] and spanning 15 of the 34 phyla known to occur in the ocean. But the story for microbes remains murkier, given the discovery of 1800 genomic microbial species and 1.2 million new genes in $200 \mathrm{~L}$ of Sargasso Sea surface water [90]. The recent discovery of deep-living microbes in the ocean crust [8] in tandem with the extraordinary number of rare species in the microbial realm [12] makes geographic prediction of unknowns for microbes extremely difficult. A recent examination of fishes provides some insight into the habitat types that offer the highest potential for new discovery. Fishes represent the greatest certainty in terms of knowns and unknowns because they are the best-known animal group taxonomically other than marine mammals. Examination of species discovery curves indicates 1000-4000 undiscovered marine fishes, with the largest gaps in the deep sea [91] and significant potential in tropical coastal ecosystems [92].

Considering the state of knowledge of biodiversity patterns more broadly, coastal biodiversity appears highest in the tropical IndoPacific, decreasing towards the poles for better known groups (fishes, corals, cephalopods), with some notable exceptions (seals, seagrasses) [93]. Temperate biodiversity peaks appear more typical for oceanic species such as tunas, squids, cetaceans, and euphausiids. Decreasing diversity with increasing latitude has also been reported for deep-sea fauna [94] and for coastal bivalve molluscs [95], and linked to temperature [93] and energy input $[94,95]$. Most sampling has focussed on northern hemisphere temperate latitudes, decreasing in effort with depth [78] and decreasing sizes of organisms [88].

But total habitat area and sampling effort add further complication; coral reef habitats cover a relatively small proportion of ocean environments $(<0.2 \%)$ but harbor significant undescribed biodiversity because they are so poorly sampled [50,92]. To illustrate this point, sampling of brachyuran crabs from just 22 coral heads from the remote Pacific Northern Line Islands yielded 30\% of the total brachyurans recorded from all of European seas, which are among the best studied oceans in the world and cover an immensely larger area than 22 coral heads [50]. Coral reef biologists have generated projections of $\sim 1$ million [96] to 2.5 million [97] species from coral reefs alone based on different extrapolation methods.

Deep-sea environments offer a particularly fertile environment for species discovery ranging from invertebrates [98] to fishes [91]. Despite general declines in biomass and abundance related to strong food limitation, deep-sea benthic ecosystems generally support many species per number of individuals relative to most environments [58]. Of particular note, deep-sea ecosystems typically harbor many rare species [7], which creates a challenge in trying to fully sample a given region, but rarity also creates op- portunities for bioprospecting. Deep-sea environments comprise some $90 \%$ of the global biosphere by volume and > 55\% of Earth's surface, and science has sampled just a few percent of its immense content [2]. Indeed, the cumulative total of deep seafloor sampled to date for sedimentary fauna covers just a few square meters for the smallest animals (meiofauna, or animals 44-300 microns) [82] and a few football fields for slightly larger organisms (macrofauna, or animals $>300$ microns) [4]. The water column of the deep ocean also offers a massive volume of habitat that may represent the least sampled habitat on Earth [78]. Thus, the potential for species discovery in the deep ocean remains almost unlimited for the foreseeable future.

Reduced diversity typically characterizes special deep-sea environments such as hydrothermal vents, cold seeps, upwelling regions, and trenches [98], however, as noted earlier, the organisms that utilize these environments often display unique physiological adaptations to cope with the unusual conditions. In some cases, these adaptations result in organisms distinct from other habitats at higher taxonomic levels (e.g. family, order). This high "taxonomic distinctness" may offer particular promise for bioprospectors because organisms may differ fundamentally from any other known relatives [66]. One other aspect of these special environments merits comment. The relatively discrete, discontinuity of many of these habitats differs from most ocean environments that are generally perceived as "open" with a free exchange of individuals. The relative isolation of these special environments can promote genetic and even species divergence from similar habitats elsewhere in the deep sea, explaining the distinct biogeography reported for hydrothermal vents and seeps [65] as well as trenches [99], for example.

Despite reports of generally decreased diversity at higher latitudes $[93,100]$, polar ecosystems may not be as species depauperate as previously assumed. Comparison of sampling effort and species reported for Canadian waters indicates more species in the Arctic than the Atlantic, despite few samples collected [101]. Thus, polar systems also offer potential for discovery, particularly under multiyear ice habitats that remain largely unsampled $[53,57]$.

Rarity adds one further complication regarding where to look for bioactive compounds. Ecologists have long known that some marine species may be quite common and others quite rare; indeed, several studies note the frequency of rare species, whether referring to microbes [12] or deep-sea invertebrates [7]. Rarity may refer to low numbers of individuals of a species in a region or total numbers of regions in which a species is found, but either characteristic adds an additional challenge for bioprospectors in terms of "missed opportunities" in the form of never sampling a given rare species. Bioactive compounds have been isolated from rare as well as common species. For example, the sponge Lissodendoryx sp., known from a single New Zealand peninsula, produces a strong antitumor compound, whereas the bryozoan $\mathrm{Bu}$ gula neritina, the source of an cytostatic compound, spans a wide range of tropical and temperate coastal environments [102]. Acknowledging the challenge of rare species and not knowing whether a new natural product will come from a common or rare species adds a challenge to the search for new products. 


\section{Whence? The Geography of Bioactive Compounds} $\nabla$

So where do new marine natural product discoveries occur? A recent analysis of marine invertebrate product discoveries since the 1990s reported more than $60 \%$ of discoveries from the Northern Hemisphere, and $\sim 55 \%$ from the tropics [6]; the Pacific accounted for $\sim 63 \%$, with $\sim 20 \%$ from the Atlantic and $\sim 13 \%$ from the Pacific. Not surprisingly, almost half of new marine invertebrate natural products came from Asian countries, reflecting high levels of natural product research activity in Japan, Taiwan, and China. But this same analysis shows apparent shifts in effort over time, with increasing proportions of discoveries from the tropics and decreasing contributions from temperate environments. Hotspots of natural product discovery also shifted spatially, from Japan and Australia in the 1990s to Japan, China, and PolynesiaMicronesia since 2000 [103]. In the context of Large Marine Ecosystems [104], the Kuroshio and South China Sea lead the way for marine bioproducts, followed by the Caribbean and East China Seas, although this pattern partly reflects some countries registering multiple closely related products.

To some extent, these patterns reflect a shift in effort from waters of developed nations with a strong science infrastructure (North America, Mediterranean, Japan) to waters where science capacity has expanded rapidly (China and, to a lesser extent, PolynesiaMicronesia), but they also reflect increasing recognition of global patterns of diversity. Therefore, the unknowns of biodiversity map loosely onto patterns of new invertebrate natural products but a clear bias towards accessible shallow waters.

\section{Who - The Taxonomy of Natural Product Discovery $\nabla$}

Even in the last decades, biodiversity discoveries led taxonomists to completely redraw the Tree of Life that describes relationships among life on Earth. In 1990, a three-domain system comprised of Bacteria, Archaea (superficially similar to bacteria but structurally different), and Eukarya (fungi, plants, animals, single-celled protistans) replaced the five kingdom system that dominated textbooks for generations [105]. This realignment created controversy; for example, some key similarities between Archaea and Eukarya point to a two-domain system [106]. While this realignment debate may appear esoteric from a natural products point of view, it illustrates that at the very highest level of biological diversity - the domain - taxonomists continue to realign relationships based on morphologies, physiologies, and, of course, genetics. These realignments follow from documentation of fundamentally different biological capacities in different organisms. For example, in the last decade or so, we learned that Archaea, a group previously thought limited to extreme environments, may dominate microbial biomass in the deep ocean $[107,108]$. We also first learned about anammox, a novel metabolic pathway in marine sediments that oxidizes ammonium, in 2001 [109]. In short, we know metabolites produced by marine microbes exhibit a wide range of bioactive properties [110], and evaluation of the marine microbial world and its potential for natural products has really just begun.

Marine animals have already yielded a wide range of natural products; in decreasing numbers of compounds to date, these include terpenoids, alkaloids, aliphatics, steroids, carbohydrates, amino acids and peptides, and others [6]. Although the complex approval process from natural product discovery to commercial product has contributed to relatively modest numbers of ma- rine-derived natural products on the market [111], the wide range of marine organisms from which natural products have been discovered points to tremendous potential.

A recent analysis of taxonomic distribution of natural product discovery across groups of animals [6] demonstrates particular promise in some phyla. The sponges (Porifera) alone account for almost half of new natural products since 1990, producing a wide range of bioactive compounds [111], with corals and jellies (Cnidaria) adding another 30\%. Seastars and relatives (Echinodermata), vertebrates (Chordata), and molluscs (Mollusca) add more than 5\% each, with additional discoveries in polychaetes (Annelida), moss animals (Bryozoa), flatworms (Platyhelminthes), acorn worms and relatives (Hemichordata), lamp shells (Brachiopoda), and crustaceans (Arthropoda).

Interestingly, new natural products to date suggest contrasting geographic sources for new marine bioproducts in different taxa [6]. Since 1990, Porifera and Cnidaria accounted for most temperate $(>67 \%)$ and tropical (> $87 \%$ ) new marine natural products, whereas Echinodermata dominates polar natural products (>40\%). Of all taxa, the order Alcyonacea (soft corals and fans) has contributed more new natural products than any other, irrespective of geography (19.6\% of polar, $16.5 \%$ of temperate, and $34.6 \%$ of tropicals).

The taxonomic focus of marine natural product discovery has also shifted over the last decade. A leading focus on Porifera that began to take off in the early 1980s peaked in discovery of marine natural products around 2000 and has remained a leading source of products [112]. Cnidarians, though not an early focus of product development, have attracted steadily increasing interest that has levelled off since 2013 and now rival sponges as a taxonomic source of products. Around 2000, interest in Ascomycota (Fungi) and Bacteria began to rise sharply and will likely continue to increase and surpass Porifera and Cnidaria in their proportional contribution to marine natural products as the natural product powerhouses.

\section{The Irony of Marine Biodiversity and Marine Bioproduct Research Needs \\ $\nabla$}

The remarkable advances in genetics and biochemistry in recent decades juxtapose significant practical deterrents to marine natural bioproduct research: (1) As demonstrated during the CoML, taxonomic effort on new species discovery focuses on larger, charismatic taxa such as fishes, molluscs, and crustaceans rather than taxonomic groups that show the greatest promise for marine products ( Fig. 1). (2) A geographic disconnect in centers of scientific capacity in taxonomy and biological diversity hotspots constrains new species discovery, with the bulk of morphologically and genetically based taxonomy in temperate developed countries and the bulk of diversity hotspots in tropical environments of developing nations. (3) A geographic disconnect between scientific capacity for marine bioproduct development and the most promising taxa and environments limits new product discovery. (4) The retirement of many practicing taxonomists without replacements reflect a low societal priority for marine taxonomic research, which hinders rates of new species descriptions $[79,80]$.

In comparing the taxa that show the most promise of new species with those that show the greatest promise of yielding marine natural products, several striking gaps emerge. Among invertebrates, the sponges and Cnidaria, and to a lesser extend the Echi- 


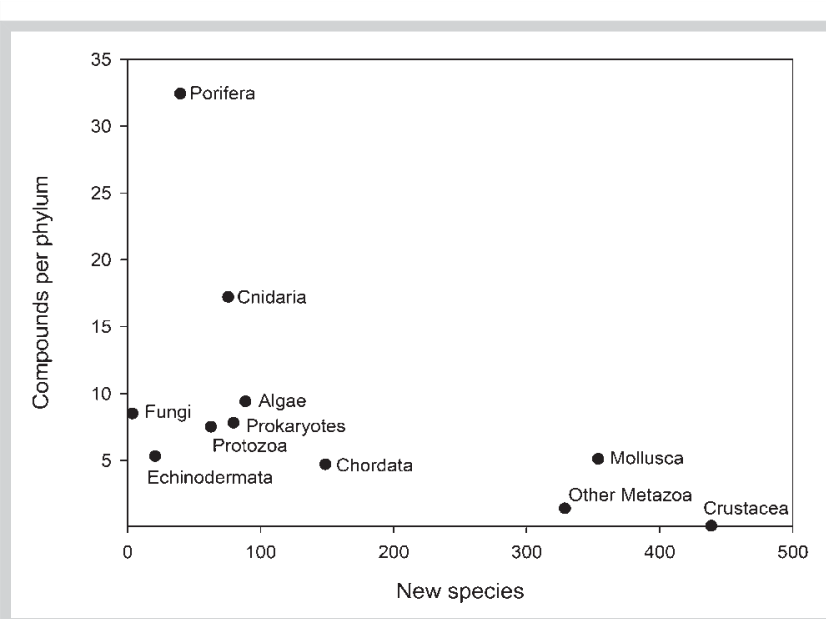

Fig. 1 Comparison of taxonomy of species discovery to taxonomy of natural products. Data on annual rates of species discovery are based on published values [79] from 2002-2003 and assume modest year-to-year variation in the discovery rate. Published values of compounds per phylum as of 2015 [112].

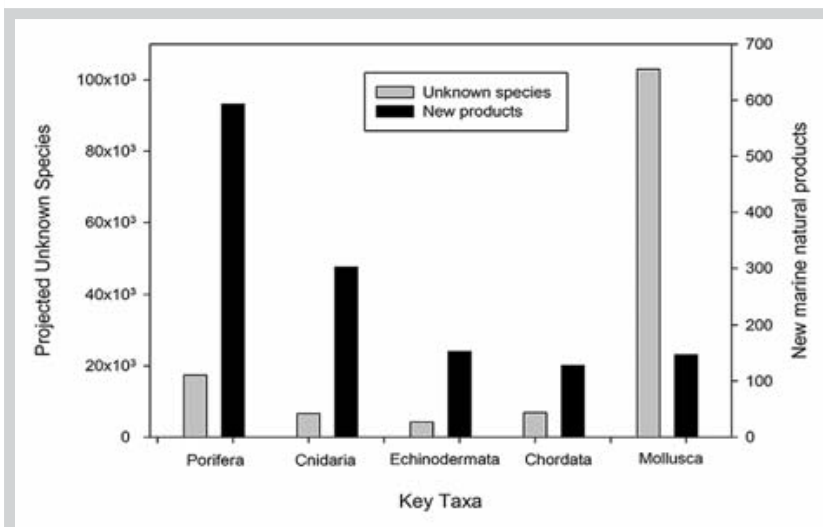

Fig. 2 Comparison of projected unknowns for taxa commonly tested for bioproduct potential. Note different $y$-axes. Data on unknown species [2] and marine products discovered 1990-2012 [3] show that some new products come from relatively well-known phyla such as Chordata, Cnidaria, and Echinodermata, whereas others come from phyla that are not well known, such as Mollusca and Porifera.

noderms, offer the most promise for bioproducts based on discoveries to date ( $\mathbf{O}$ Fig. $\mathbf{2}$ ), noting that many of these natural products are derived from microbes associated with these invertebrates and that these microbes may vary in composition over modest distances. Although these groups include many potential undiscovered species (Porifera 67\% unknown, Cnidaria 20-40\% unknown, Echinodermata 25-45\% unknown) [5], the least known taxa (e.g., Mollusca, Nematoda, Platyhelminthes, Protista, some groups of Crustacea, and multiple lesser known phyla) have not figured greatly in marine bioprospecting ( 0 Fig. 2). Two separate lines of evidence support the assertion of a mismatch. The "star performers" for new products (Porifera, algae, Cnidaria) clearly differ from the "star performers" for new species discoveries (Mollusca, Crustacea, Chordata, and other metazoans), whether considering the number of species yielding new products or products per phylum. This mismatch extends into the projected unknowns of diversity, suggesting no relationship between bioprospecting focus and unknown species diversity ( $\odot$ Fig. 2). Whether this mismatch between unknown and untapped species reflects a bias in where bioprospectors have looked or a real paucity of potential products in some taxa is difficult to assess, but both factors likely contribute.

Geographically, new product discovery and biodiversity hotspots partially coincide, but with clear differences likely driven by science capacity and research investment. Not surprisingly, the majority of product discoveries have come from the Northern Hemisphere, and particularly from industrialized countries with a strong science capacity. In the case of some groups of organisms such as seaweeds, the success in Japan, China, Taiwan, and Korea corresponds to a region of strong research investment [113] and high levels of known macroalgal diversity and endemism [114]. Large numbers of bioproduct discoveries coincide with some invertebrate diversity hotspots such as Indonesia and China, but other biodiversity hotspots such as coastal Africa, South America, the Red Sea, the Caribbean, and the South Pacific produced modest numbers of marine natural products from 2000-2009 [6], clearly reflecting undersampling for both biodiversity and for natural product potential.

\section{Conclusions and Priorities}

$\nabla$

As a marine ecologist bringing a biodiversity perspective on the future of marine bioprospecting, I believe the potential looks both compelling and exciting, but points to a need to manage expectations. The great promise of marine bioproducts built expectations of massive payoffs that, in the vast majority of cases, will never occur. Marine ecologists themselves helped fuel this expectation in arguing for conservation and sustainable practices for future economic benefits [115], but this enthusiasm has raised (legitimate) concerns about biopiracy. These concerns catalyze protectionism that limits potential discovery in developing nations that may lack the capacity or resources to develop natural products. In the absence of the benefit of sharing agreements outlined in the Nagoya Protocol, this concern will seriously limit future discovery and marine bioprospecting, noting the taxonomic and geographic distribution of many past success stories. Many opportunities remain for the discovery of marine bioproducts, but the spatial mismatch between science capacity, hotspots for biodiversity and bioproducts, and resource access and development adds a great challenge. Without question, marine resources offer promise for many developing nations with some of the richest biodiversity globally in their jurisdictional waters [113]. Relatively few documented global extinctions in the ocean [116] juxtapose many local and regional extirpations (and associated genetic losses) [117] and suggest urgency in stemming the loss of biodiversity $[118,119]$ and marine bioproduct potential that threatens "future options".

For most species that have yielded bioproducts to date, we lack anywhere near sufficient data to apply the sorts of management plans developed for fisheries, for example, to ensure species sustainability. Indeed, for future options and marine bioprospecting, we rarely know which species to protect. The strong call for marine protected areas (MPAs) from marine scientists $[120,121]$ offers the most promising strategy for maintaining future options, particularly if efforts include known biodiversity hotspots [122]. By protecting habitats, MPAs offer at least minimal protection for unknown as well as known species. MPAs may, in some instances, 
encompass a diversity of permitted uses, and marine bioproduct testing and development often require modest numbers of individuals compared to activities such as commercial fisheries or aquaculture. Marine bioprospectors could, therefore, add a contrasting and potentially effective voice for ocean conservation while simultaneously preserving future options.

\section{Conflict of Interest}

\section{$\nabla$}

The author declares no conflict of interest.

\section{Acknowledgements \\ $\nabla$}

The author thanks Bioprosp: The 7th International Conference on Marine Bioprospecting and Kjersti Lie Gabrielsen for the speaking invitation that made him think about the ideas presented here, and to Deniz Tasdemir for the invitation to put them in writing. He also thanks Philippe Archambault and Kim Juniper for discussions that helped in framing this review, and two anonymous reviewers who provided insightful comments on an earlier draft. Finally, he thanks the Consortium for Ocean Leadership and Kristen Yarincik for their hospitality during the sabbatical that supported the writing of the manuscript.

\section{References}

1 Molinski TF, Dalisay DS, Lievens SL, Saludes JP. Drug development from marine natural products. Nat Rev Drug Discov 2009; 8: 69-85

2 Snelgrove PVR. Discoveries of the Census of Marine Life: making ocean life count. Cambridge: Cambridge University Press; 2010

3 McIntyre A. Life in the world's oceans: diversity, distribution, and abundance. Chichester: Wiley-Blackwell; 2010

4 Ramirez-Llodra E, Brandt A, Danovaro R, De Mol B, Escobar E, German CR, Levin LA, Martinez Arbizu P, Menot L, Buhl-Mortensen P, Narayanaswamy BE, Smith CR, Tittensor DP, Tyler PA, Vanreusel A, Vecchione $M$. Deep, diverse and definitely different: unique attributes of the world's largest ecosystem. Biogeosciences 2010; 7: 2851-2899

5 Appeltans W, Ahyong ST, Anderson G, Angel MV, Artois T, Bailly N, Bamber R, Barber A, Bartsch I, Berta A. The magnitude of global marine species diversity. Curr Biol 2012; 22: 2189-2202

6 Leal MC, Puga J, Serôdio J, Gomes NCM, Calado R. Trends in the discovery of new marine natural products from invertebrates over the last two decades - where and what are we bioprospecting? PLoS One 2012; 7: e30580

7 Grassle JF, Maciolek NJ. Deep-sea species richness - regional and local diversity estimates from quantitative bottom samples. Am Nat 1992; 139: $313-341$

8 Parkes RJ, Cragg BA, Bale SJ, Getlifff JM, Goodman K, Rochelle PA, Harvey $S M$. Deep bacterial biosphere in Pacific Ocean sediments. Nature 1994; 371: 410-413

9 Shaffer SA, Tremblay Y, Weimerskirch H, Scott D, Thompson DR, Sagar PM, Moller H, Taylor GA, Foley DG, Block BA, Costa DP. Migratory shearwaters integrate oceanic resources across the Pacific Ocean in an endless summer. Proc Natl Acad Sci U S A 2006; 103: 12799-12802

10 Vecchione M, Bergstad OA, Byrkjedal I, Falkenhaug T, Gebruk AV, Godø OR, Gislason A, Heino M, Høines ÅS, Menezes GMM, Piatkowski U, Priede IG, Skov H, Søiland H, Sutton T, de Lange Wennick T. Biodiversity patterns and processes on the Mid-Atlantic Ridge. In: McIntyre A, editor. Life in the world's oceans: diversity, distribution, and abundance. Chichester: Wiley-Blackwell; 2010: 103-121

11 Danovaro R, Snelgrove PVR, Tyler PA. Challenging the paradigms of deep-sea ecology. Trends Ecol Evol 2014; 29: 465-474

12 Sogin ML, Morrison HG, Huber JA, Welch DM, Huse SM, Neal PR, Arrieta $J M$, Herndl GJ. Microbial diversity in the deep sea and the underexplored "rare biosphere". Proc Natl Acad Sci U S A 2006; 103: $12115-12120$
13 Martins A, Vieira H, Gaspar H, Santos S. Marketed marine natural products in the pharmaceutical and cosmeceutical industries: tips for success. Mar Drugs 2014; 12: 1066-1101

14 Macilwain $C$. When rhetoric hits reality in debate on bioprospecting. Nature 1998; 392: 535-540

15 Mayer AM, Glaser KB, Cuevas C, Jacobs RS, Kem W, Little RD, McIntosh $J M$, Newman DJ, Potts BC, Shuster DE. The odyssey of marine pharmaceuticals: a current pipeline perspective. Trends Pharmacol Sci 2010; 31: 255-265

16 Schumacher M, Kelkel M, Dicato M, Diederich M. Gold from the sea: marine compounds as inhibitors of the hallmarks of cancer. Biotechnol Adv 2011; 29: 531-547

17 Fenical $W$. Marine pharmaceuticals past, present, and future. Oceanography 2006; 19: 111-119

18 Vo TS, Ngo DH, Ta QV, Kim SK. Marine organisms as a therapeutic source against herpes simplex virus infection. Eur J Pharm Sci 2011; 44: 11-20

19 Kim SK. Marine nutriceuticals: prospects and perspectives. Boca Raton: CRC Press; 2013

20 Guérard F, Decourcelle N, Sabourin C, Floch-Laizet C, Le Grel L, Le Floch P, Gourlay F, Le Delezir R, Jaouen P, Bourseau P. Recent developments of marine ingredients for food and nutraceutical applications: a review. J Sci Halieut Aquat 2010; 2: 21-27

21 Nelson FP, Rumsfield J. Cosmetics content and function. Int J Dermatol 1988; 27: 665-672

22 Shick JM, Dunlap WC. Mycosporine-like amino acids and related Gadusols: biosynthesis, accumulation, and UV-protective functions in aquatic organisms. Annu Rev Physiol 2002; 64: 223-262

23 Osborn AR, Almabruk KH, Holzwarth G, Asamizu S, LaDu J, Kean KM, Karplus PA, Tanguay RL, Bakalinsky AT, Mahmud T. De novo synthesis of a sunscreen compound in vertebrates. Elife 2015; 4: e05919

24 Thomas NV, Kim SK. Beneficial effects of marine algal compounds in cosmeceuticals. Mar Drugs 2013; 11: 146-164

25 Callow JA, Callow ME. Trends in the development of environmentally friendly fouling-resistant marine coatings. Nat Commun 2011; 2: 244

26 Petrone L. Molecular surface chemistry in marine bioadhesion. Adv Colloid Interface Sci 2013; 195-196: 1-18

27 Fletcher GL, Shears MA, King MJ, Davies PL, Hew CL. Evidence for antifreeze protein gene transfer in Atlantic salmon (Salmo salar). Can J Fish Aquat Sci 1988; 45: 352-357

28 Wei N, Quarterman J, Jin YS. Marine macroalgae: an untapped resource for producing fuels and chemicals. Trends Biotechnol 2013; 31: 70-77

$29 \mathrm{Mocz}$ G. Fluorescent proteins and their use in marine biosciences, biotechnology, and proteomics. Mar Biotechnol 2007; 9: 305-328

30 Trincone A. Marine enzymes for biocatalysis: sources, biocatalytic characteristics and bioprocesses of marine enzymes. Cambridge: Woodhead Publishing; 2013

31 Brown CJ, Smith SJ, Lawton P, Anderson JT. Benthic habitat mapping: a review of progress towards improved understanding of the spatial ecology of the seafloor using acoustic techniques. Estuar Coast Shelf Sci 2011; 92: 502-520

32 Guisan A, Zimmermann NE. Predictive habitat distribution models in ecology. Ecol Modell 2000; 135: 147-186

33 Davies AJ, Wisshak M, Orr JC, Murray Roberts J. Predicting suitable habitat for the cold-water coral Lophelia pertusa (Scleractinia). Deep Sea Res Part 1 Oceanogr Res Pap 2008; 55: 1048-1062

34 Cottin AG, Forbes DL, Long BF. Shallow seabed mapping and classification using waveform analysis and bathymetry from SHOALS lidar data. Can J Rem Sens 2009; 35: 422-434

35 Van Dover CL, Humphris SE, Fornari D, Cavanaugh CM, Collier R, Goffredi $S K$, Hashimoto J, Lilley MD, Reysenbach AL, Shank TM, Von Damm KL, Banta A, Gallant RM, Gotz D, Green D, Hall J, Harmer TL, Hurtado LA, Johnson P, McKiness ZP, Meredith C, Olson E, Pan IL, Turnipseed M, Won $Y$, Young CR, Vrijenhoek RC. Biogeography and ecological setting of Indian Ocean hydrothermal vents. Science 2001; 294: 818-823

36 Baker MC, Ramirez-Llodra EZ, Tyler PA, German CR, Boetius A, Cordes EE, Dubilier N, Warén A. Biogeography, ecology and vulnerability of chemosynthetic ecosystems in the deep sea. In: McIntyre A, editor. Life in the world's oceans: diversity, distribution, and abundance. Chichester: Wiley-Blackwell; 2010: 161-183

37 Shepard FP, Curray JR, Inman DL, Murray EA, Winterer EL, Dill RF. Submarine geology by diving saucer. Science 1964; 145: 1042-1046

38 Cavanaugh CM. Symbiotic chemoautotrophic bacteria in marine invertebrates from sulfide-rich habitats Nature 1983; 302: 58-61

39 Juniper SK. Technological, environmental, social, and economic aspects of marine genetics resources. IUCN Information Papers for the Interses- 
sional Workshop on Marine Genetic Resources. Bonn, Germany: International Union for the Conservation of Nature, Environmental Law Center; 2013

40 Luther GW, Rozan TF, Taillefert M, Nuzzio DB, Di Meo C, Shank TM, Lutz $R A$, Cary SC. Chemical speciation drives hydrothermal vent ecology. Nature 2001; 410: 813-816

41 Rudnick DL, Davis RE, Eriksen CC, Fratantoni DM, Perry MJ. Underwater gliders for ocean research. Mar Tech Soc J 2004; 38: 73-84

42 Roemmich D, Johnson GC, Riser S, Davis R, Gilson J, Owens WB, Garzoli SL, Schmid C, Ignaszewski M. The Argo Program: Observing the global ocean with profiling floats. Oceanography 2009; 22: 34-43

43 Wernli RL. AUVs - a technology whose time has come. Proceedings of the 2002 International Symposium on Underwater Technology, Tokyo; 2002: 309-314

44 Barnes CR, Tunnicliffe V. Building the world's first multi-node cabled ocean observatories (NEPTUNE Canada and VENUS, Canada): science, realities, challenges and opportunities. Kobe: OCEANS 2008 - MTS/ IEEE Kobe Techno-Ocean; 2008: 1-8

45 Knowlton N. Sibling species in the sea. Annu Rev Ecol Syst 1993; 24: $189-216$

46 WoRMS Editorial Board. WoRMS - World Register of Marine Species. Available at www.marinespecies.org. Accessed September 30, 2015

47 Hebert PDN, Cywinska A, Ball SL, deWaard JR. Biological identifications through DNA barcodes. Proc Biol Sci 2003; 270: 313-321

48 Kress WJ, Wurdack KJ, Zimmer EA, Weigt LA, Janzen DH. Use of DNA barcodes to identify flowering plants. Proc Natl Acad Sci U S A 2005; 102: 8369-8374

49 Pace NR. A molecular view of microbial diversity and the biosphere. Science 1997; 276: 734-740

50 Knowlton N, Brainard RE, Fisher R, Moews M, Plaisance L, Caley MJ. Coral reef biodiversity. In: McIntyre A, editor. Life in the world's oceans: diversity, distribution, and abundance. Chichester: Wiley-Blackwell; 2010: $65-77$

51 Scholin C, Doucette G, Jensen S, Roman B, Pargett D, Marin III R, Preston C, Jones W, Feldman J, Everlove C, Harris A, Alvarado N, Massion E, Birch J, Greenfield D, Vrijenhoek R, Mikulski C, Jones K. Remote detection of marine microbes, small invertebrates, harmful algae and biotoxins using the environmental sample processor (ESP). Oceanography 2009; 22: $158-167$

52 Rogers $A D$, Tyler PA, Connelly DP, Copley JT, James $R$, Larter RD, Linse $K$, Mills RA, Garabato AN, Pancost RD, Pearce DA, Polunin NVC, German CR, Shank T, Boersch-Supan PH, Alker BJ, Aquilina A, Bennett SA, Clarke A, Dinley RJJ, Graham AGC, Green DRH, Hawkes JA, Hepburn L, Hilario A, Huvenne VAI, Marsh L, Ramirez-Llodra E, Reid WDK, Roterman CN, Sweeting CJ, Thatje S, Zwirglmaier K. The discovery of new deep-sea hydrothermal vent communities in the Southern Ocean and implications for biogeography. PLoS Biol 2012; 10: e1001234

53 Gradinger R, Bluhm BA, Hopcroft RR, Gebruk A, Kosobokova K, Sirenko BI, Wellslawski JM. Marine life in the Arctic. In: McIntyre A, editor. Life in the world's oceans: diversity, distribution, and abundance. Chichester: Wiley-Blackwell; 2010: 183-202

54 Gjedrem T. Genetic improvement of cold-water fish species. Aquac Res 2004; 31: 25-33

55 Gradinger R, Meiners K, Plumley G, Zhang Q Bluhm BA. Abundance and composition of the sea-ice meiofauna in off-shore pack ice of the Beaufort Gyre in summer 2002 and 2003. Polar Biol 2005; 28: 171-181

56 Melnikov I. The Arctic Sea Ice Ecosystem. Amsterdam: Gordon and Breach Science Publishers; 1997

57 Gutt J, Hosie G, Stoddart M. Marine life in the Antarctic. In: McIntyre A, editor. Life in the world's oceans: diversity, distribution and abundance. Chichester: Wiley-Blackwell; 2010: 203-220

58 Snelgrove PVR, Smith CR. A riot of species in an environmental calm: the paradox of the species-rich deep-sea floor. Oceanogr Mar Biol Ann Rev 2002; 40: 311-342

59 Broch $H$. Stylasteridae. The Danish Ingolf Expedition. Copenhagen: Bianco Luno; 1914; 5: 1-25

60 Tittensor D, Baco AR, Brewin PE, Clark MR, Consalvey M, Hall-Spencer J, Rowden AA, Schlacher T, Stocks KI, Rogers AD. Predicting global habitat suitability for stony corals on seamounts. J Biogeogr 2009; 36: 11111128

61 Guinotte JM, Davies AJ. Predicted deep-sea coral habitat suitability for the U.S. west coast. PLoS One 2014; 9: e93918

62 Roberts JM, Wheeler AJ, Freiwald A. Reefs of the deep: the biology and geology of cold-water coral ecosystems. Science 2006; 312: 543-547
63 Olson JB, Harmody DK, Bej A, McCarthy PJ. Tsukamurella spongiae sp. nov., a novel actinomycete isolated from a deep-water marine sponge. Int J Syst Evol Microbiol 2007; 57: 1478-1481

64 Grassle JF. Hydrothermal vent animals: distribution and biology. Science 1985; 229: 713-717

65 Van Dover CL, German CR, Speer KG, Parson LM, Vrijenhoek RC. Evolution and biogeography of deep-sea vent and seep invertebrates. Science 2002; 295: 1253-1257

66 Tunnicliffe V, McArthur AG, McHugh D. A biogeographical perspective of the deep-sea hydrothermal vent fauna. Adv Mar Biol 1998; 34: 355442

67 Hashimoto J, Ohta S, Gamo T, Chiba H, Yamaguchi T, Tsuchida S, Okudaira T, Watabe H, Yamanaka T, Kitazawa M. First hydrothermal vent communities from the Indian Ocean discovered. Zoolog Sci 2001; 18: 717-721

68 Edmonds HN, Michael PJ, Baker ET, Connelly DP, Snow JE, Langmuir CH, Dick HJB, Mühe R, German CR, Graham DW. Discovery of abundant hydrothermal venting on the ultraslow-spreading Gakkel Ridge in the Arctic Ocean. Nature 2003; 421: 252-256

69 Paull CK, Jull AJT, Toolin LJ, Linick T. Stable isotope evidence for chemosynthesis in an abyssal seep community. Nature 1985; 317: 709-711

70 Danovaro $R$, Company JB, Corinaldesi C, D’Onghia G, Galil B, Gambi C, Gooday AJ, Lampadariou N, Luna GM, Morigi C, Olu K, Polymenakou P, Ramírez-Llodra E, Sabbatini A, Sardà F, Sibuet M, Tselepides A. Deep-sea biodiversity in the Mediterranean Sea: the known, the unknown, and the unknowable. PLoS One 2010; 5: e11832

71 Milkov AV. Worldwide distribution of submarine mud volcanoes and associated gas hydrates. Mar Geol 2000; 167: 29-42

72 Domack EW, Taviani M, Rodriguez A. Recent sediment remolding on a deep shelf, Ross Sea: implications for radiocarbon dating of Antarctic marine sediments. Quat Sci Rev 1999; 18: 1445-1451

73 Levin LA. Oxygen minimum zone benthos: adaptation and community response to hypoxia. Oceanogr Mar Biol Ann Rev 2003; 41: 1-45

74 Danovaro $R$, Coninaldesi C, Dell'Anno A, Fabiono M, Corselli $C$. Viruses, Prokaryotes and DNA in the sediments of a deep-hypersaline anoxic basin (DHAB) of the Mediterranean Sea. Environ Microbiol 2005; 7: 586-592

75 Edgcomb V, Orsi W, Taylor G, Vdacny P, Taylor C, Suarez P, Epstein S. Accessing marine protists from the anoxic Cariaco Basin. ISME J 2011; 5: $1237-1241$

76 Danovaro R, Dell'Anno A, Pusceddu A, Gambi C, Heiner I, Kristensen RM. The first metazoa living in permanently anoxic conditions. BMC Biol 2010; 8: 30

77 Pagès F, Flood P, Youngbluth M. Gelatinous zooplankton net-collected in the Gulf of Maine and adjacent submarine canyons: new species, new family (Jeanbouilloniidae), taxonomic remarks and some parasites. Sci Mar 2006; 70: 363-379

78 Webb TJ, Vanden Berghe E, O'Dor R. Biodiversity's big wet secret: the global distribution of marine biological records reveals chronic underexploration of the deep pelagic ocean. PLoS One 2010; 5: e10223

79 Bouchet $P$. The magnitude of marine biodiversity. In: Duarte CM, editor. The exploration of marine biodiversity: scientific and technological challenges. Madrid, Spain: Fundacion BBVA; 2006

80 Giangrande A. Biodiversity, conservation, and the 'Taxonomic impediment'. Aquat Cons Mar Fresh Ecosyst 2003; 13: 451-459

81 de Carvalho M, Bockmann F, Amorim D, Brandão C, de Vivo M, de Figueiredo J, Britski $H$, de Pinna MC, Menezes $N$, Marques FL, Papavero N, Cancello E, Crisci J, McEachran J, Schelly R, Lundberg J, Gill A, Britz R, Wheeler Q Stiassny MJ, Parenti L, Page L, Wheeler W, Faivovich J, Vari R, Grande L, Humphries $C$, DeSalle R, Ebach $M$, Nelson $G$. Taxonomic impediment or impediment to taxonomy? A commentary on systematics and the cybertaxonomic-automation paradigm. Evol Biol 2007; 34: 140-143

82 Lambshead PJD. Recent developments in marine benthic biodiversity research. Oceanis 1993; 19: 5-24

83 Costello MJ, Wilson S, Houlding B. Predicting total global species richness using rates of species description and estimates of taxonomic effort. Syst Biol 2012; 61: 871-883

84 Mora C, Tittensor DP, Adl S, Simpson AGB, Worm B. How many species are there on Earth and in the ocean? PLoS Biol 2011; 9: e1001127

85 Arrieta JM, Arnaud-Haond S, Duarte CM. What lies underneath: conserving the oceans' genetic resources. Proc Natl Acad Sci U S A 2010; 107: $18318-18324$

86 Groeneveld JC, Griffiths CL, van Dalsen AP. A new species of spiny lobster, Palinurus barbarae (Decapoda, Palinuridae) from Walters Shoals on the Madagascar Ridge. Crustaceana 2006; 79: 821-833 
87 Chisholm SW, Olson RJ, Zettler ER, Goericke R, Waterbury JB, Welschmeyer NA. A novel free-living prochlorophyte occurs at high cell concentrations in the oceanic euphotic zone. Nature 1988; 334: 340-343

88 Incze LS, Lawton P, Ellis SL, Wolff NH. Biodiversity assessment and its application for the management of the Gulf of Maine. In: McIntyre A, editor. Life in the world's oceans: diversity, distribution, and abundance. Chichester: Wiley-Blackwell; 2010: 46-63

89 Bucklin AC, Nishida S, Schnack-Schiel S, Wiebe PH, Lindsay D, Machida RJ, Copley NJ. Marine zooplankton. In: McIntyre A editor. Life in the world's oceans: diversity, distribution, and abundance. Chichester: Wiley-Blackwell; 2010: 247-265

90 Venter JC, Remington $K$, Heidelberg JF, Halpern AL, Rusch D, Eisen JA, Wu D, Paulsen I, Nelson KE, Nelson W, Fouts DE, Levy S, Knap AH, Lomas $M W$, Nealson $K$, White O, Peterson J, Hoffman J, Parsons R, Baden-Tillson $H$, Pfannkoch C, Rogers YH, Smith HO. Environmental genome shotgun sequencing of the Sargasso Sea. Science 2004; 304: 66-74

91 Mora C, Tittensor DP, Myers RA. The completeness of taxonomic inventories for describing the global diversity and distribution of marine fishes. Proc Biol Sci 2008; 275: 149-155

92 Miloslavich P, Klein E. Caribbean marine biodiversity: the known and unknown. Lancaster, PA: DEStech Publications; 2005

93 Tittensor DP, Mora C, Jetz W, Lotze HK, Ricard D, Berghe EV, Worm B. Global patterns and predictors of marine biodiversity across taxa. Nature 2010; 466: 1098-1101

94 Rex MA, Stuart CT, Hessler RR, Allen JA, Sanders HL, Wilson GDF. Globalscale latitudinal patterns of species-diversity in the deep-sea benthos. Nature 1993; 365: 636-639

95 Roy K, Jablonski D, Valentine JW. Dissecting latitudinal diversity gradients: functional groups and clades of marine bivalves. Proc Biol Sci 2000; 267: 293-299

96 Reaka-Kudla ML. The global biodiversity of coral reefs: a comparison with rain forests. In: Reaka-Kudla ML, Wilson DE, Wilson EO editor. Biodiversity II: understanding and protecting our biological resources. Washington, DC: Joseph Henry Press; 1997: 83-108

97 Small AM, Adey WH, Spoon D. Are current estimates of coral reef biodiversity too low? The view through the window of a microscosm. Atoll Res Bull 1998; 458: 1-20

98 Grassle JF. Deep-sea benthic biodiversity. Bioscience 1991; 41: 464469

99 Jamieson AJ, Fujii T, Mayor DJ, Solan M, Priede IG. Hadal trenches: The ecology of the deepest places on Earth. Trends Ecol Evol 2010; 25: 190-197

100 Roy K, Jablonski D, Valentine JW, Rosenberg G. Marine latitudinal diversity gradients: tests of causal hypotheses. Proc Natl Acad Sci U S A 1998; 95: 3699-3702

101 Archambault P, Snelgrove PVR, Fisher JAD, Gagnon JM, Garbary DJ, Harvey $M$, Kenchington $E$, Lesage $V$, Levesque $M$, Lovejoy $C$, Mackas $D$, McKindsey CW, Nelson J, Pepin P, Piché L, Poulin M. From sea to sea: Canada's three oceans of biodiversity. PLoS One 2010; 5: e12182

102 Pomponi SA. The bioprocess-technological potential of the sea. J Biotechnol 1999; 70: 5-13

103 Colaco A, Martins I, Laranjo M, Pires L, Leal C, Prieto C, Costa V, Lopes H, Rosa D, Dando PR, Serrao-Santos $R$. Annual spawning of the hydrother- mal vent mussel, Bathymodiolus azoricus, under controlled aquarium conditions at atmospheric pressure. J Exp Mar Biol Ecol 2006; 333: 166-171

104 Sherman K, Alexander LM, Gold BD. Large marine ecosystems: patterns, processes, and yields. Washington, DC: AAAS; 1990

105 Woese C, Kandler O, Wheelis M. Towards a natural system of organisms: proposal for the domains Archaea, Bacteria, and Eucarya. Proc Natl Acad Sci U S A 1990; 87: 4576-4579

106 Williams TA, Foster PG, Cox CJ, Embley TM. An archaeal origin of eukaryotes supports only two primary domains of life. Nature 2013; 504: 231-236

107 Lipp JS, Morono Y, Inagaki F, Hinrichs KU. Significant contribution of Archaea to extant biomass in marine subsurface sediments. Nature 2008; 454: 991-994

108 Karner MB, DeLong EF, Karl DM. Archaeal dominance in the mesopelagic zone of the Pacific Ocean. Nature 2001; 409: 507-510

109 Dalsgaard T, Thramdrup B. Production of N2 through anaerobic ammonium oxidation coupled to nitrate reduction in marine sediments. Appl Environ Microbiol 2001; 68: 1312-1318

110 Lam KS. Discovery of novel metabolites from marine actinomycetes. Curr Opin Microbiol 2006; 9: 245-251

111 Haefner $B$. Drugs from the deep: marine natural products as drug candidates. Drug Discov Today 2003; 8: 536-544

112 Blunt JW, Copp BR, Keyzers RA, Munro MHG, Prinsep MR. Marine natural products. Nat Prod Rep 2015; 32: 116-211

113 Mazarrasa I, Olsen YS, Mayol E, Marba N, Duarte CM. Rapid growth of seaweed biotechnology provides opportunities for developing nations. Nat Biotechnol 2013; 31: 591-592

114 Kerswell AP. Global biodiversity patterns of benthic marine algae. Ecology 2006; 87: 2479-2488

115 Snelgrove PVR, Austen MC, Boucher G, Heip C, Hutchings PA, King GM, Koike I, Lambshead PJD, Smith CR. Linking biodiversity above and below the marine sediment-water interface. Bioscience 2000; 50: 1076-1088

116 Carlton JT, Geller JB, Reaka-Kudla ML, Norse EA. Historical extinctions in the sea. Annu Rev Ecol Syst 1999; 30: 515-538

117 Dulvy NK, Sadovy Y, Reynolds JD. Extinction vulnerability in marine populations. Fish Fish 2003; 4: 25-64

118 Jackson JBC. Ecological extinction and evolution in the brave new ocean. Proc Natl Acad Sci U S A 2008; 105: 11458-11465

119 Roberts CM, Hawkins JP. Extinction risk in the sea. Trends Ecol Evol 1999; 14: 241-246

120 Botsford LW, Castilla JC, Peterson CH. The management of fisheries and marine ecosystems. Science 1997; 277: 509-515

121 Roberts CM, Branch G, Bustamante RH, Castilla JC, Dugan J, Halpern BS, Lafferty KD, Leslie H, Lubchenco J, McArdle D, Ruckelshaus M, Warner $R R$. Application of ecological criteria in selecting marine reserves and developing reserve networks. Ecol Appl 2003; 13: S215-S228

122 Roberts CM, McClean CJ, Veron JEN, Hawkins JP, Allen GR, McAllister DE, Mittermeier CG, Schueler FW, Spalding M, Wells F, Vynne C, Werner TB. Marine biodiversity hotspots and conservation priorities for tropical reefs. Science 2002; 295: 1280-1284 